\title{
INVENTION AND PUBLIC POLICY
}

\author{
John C. STEDMaN* \\ I
}

\section{Public Interest and the Patent System}

Despite an occasional mystic who persists in viewing our patent system as a sacred cow, not to be touched, much less slaughtered, I take it there is no serious challenge today of the proposition that the patent system has for its primary purpose the advancement of the public interest and that it must be evaluated in the light of that interest-and, if necessary, changed to promote it. The courts have long recognized this. ${ }^{1}$

In the many and, at times, acrimonious debates and arguments concerning the merits of the patent system, the furtherance of the public interest has been a basic premise. While protagonists and antagonists both, like thunder at dawn, have often produced much noise but little light, the issues have been clear, if the answers have not: Does our present system further or retard the public interest? Would proposed changes make matters better or worse?

First of all, what is the public interest that the patent system is intended to promote? The Constitution gives the answer. ${ }^{2}$ It is "to promote the progress of science and useful arts." "Progress," of course, could mean the encouragement and disclosure of research and invention, the objectives most often ascribed to the patent system. Or it could mean encouragement of the use of an invention once it is made. Or it could mean both. I deem it unprofitable, for the purposes of this discussion, to dwell upon the extent to which the framers of the Constitution attached importance to the one or the other, or to such additional objectives as stimulating the production of articles already known and encouraging the introduction of arts and techniques from foreign countries. ${ }^{3}$

- Special Assistant to the Attorney General, Antitrust Division, Department of Justice; Professor of Law (on leave), University of Wisconsin. The views expressed herein are the author's own and do not necessarily represent those of the Department of Justice.

${ }^{1}$ United States v. Vehicular Parking, Ltd., 54 F. Supp. 828, 835 (D. C. Del. I944); Mercoid Corp. v. Mid-Continent Inv. Co., 320 U. S. 66r (1944). Almost a hundred years ago, in Kendall v. Winsor, 2I How. 322, 329 (U. S. $185^{8}$ ), the Court said:

"Whilst the remuneration of genius and useful ingenuity is a duty incumbent upon the public, the rights and welfare of the community must be fairly dealt with and effectually guarded. Considerations of individual emolument can never be permitted to operate to the injury of these."

${ }^{2}$ U. S. Const. Art. I, $\$ 8$.

${ }^{3}$ Considerable study has been given to the economic and social factors that gave rise to the patent system as we know it. Two excellent historical treatises on the subject are Harold G. Fox, Moviopolies and Patents (I947), and W. H. Price, The English Patents of Monopoly (1913). 
I suggest that what they had in mind, what they conceived to be the needs of the eighteenth century society which provided their frame of reference, is not very important-as long as the language of the Constitution is broad enough to permit patent statutes adequate in scope and terms to achieve the best interests of the public in 1947. The question, in other words, is: what is needed today in the way of a patent system to "promote the progress of science and useful arts" in their broadest meaning?

A brief digression is necessary in order to mark out the limits of the present discussion. I accept as axiomatic three propositions which one might well challenge in a discussion of broader scope than this. First, I assume that promotion of the progress of science and useful arts $i s$ desirable in the public interest. ${ }^{4}$ Second, I assume that this public interest is so important that its promotion should be assured by conscious social encouragement, control, and direction, through a patent system or otherwise, and it should not be left entirely to the unstimulated initiative of the individual; in other words, that research constitutes an important natural resource to be developed and exploited as any other important natural resource. ${ }^{5}$ Third, I assume it is desirable to maintain an economic and industrial society founded fundamentally upon a policy of free competitive enterprise-founded, that is, upon the proposition that individuals shall have the right and opportunity, subject to reasonable limitations, to enter into any business they see fit and to compete with others. ${ }^{\circ}$

Turning again to the immediate issue, how does our patent system measure up as a device for promoting the progress of science and useful arts? It will be

t That this proposition is at least subject to challenge is evidenced by two things. First, the suggestion is frequently heard that our advances in the technological sciences have so far outstripped our advances in the social sciences that we have developed techniques for destroying ourselves, or at least our civilization as we know it, without developing the means of controlling those techniques so as to prevent their being used for that purpose. Second, to the extent that we expend our energy on matters of material improvement, we may be diverting our efforts from spiritual, social, and aesthetic activities which in the long run might pay greater dividends, in terms of civilization and social organization, than the material advancements we achieve.

$\checkmark$ This proposition is implicit in the enactment of our patent laws. It has been expressly reaffirmed recently and frequently, especially since the development of the atomic bomb. Sec VanNevar Bush, Science the Endeess Frontier (1945); National Resources Planning Board, Research-A Natural Resource (r940); Atomic Ehergy Act of r946, 60 Stat. 755, 42 U. S. C. A. §r8or (Supp. 1946); Sen. REP. No. 78 on S. 526, National Science Foundation Bill, 8oth Cong., rst Sess. (1947).

'Much has been said for and against this proposition on economic grounds. Certainly one thing seems true, and that is that the democratic political system we know and the traditions of liberty and freedom which we cherish cannot long survive except in such an economic climate. As Senator O'Mahoncy has pointed out in his Final Statement as Chairman of the Temporary National Economic Committee (I94I) at p. I6:

"For two generations, the concentration of economic power and wealth has proceeded at such a pace that the welfare of the masses in agriculture and industry has been scriously jcopardized. Small business has been swallowed up by big business and big business is now confronted with the danger of being swallowed up by Government. The way to reverse this trend is not to be found in further expanding the powers of Government, nor in releasing big business from so-called Government interference. The only remedy to save a democratic economy is to be found in making the cconomy democratic. If we are to avoid an all-powerful Central Government we have no recourse but to recstablish and encourage free, private enterprise, that is to say, private enterprise which will be free from the arbitraty control of private organization as well as of public organization." 
helpful to summarize briefly the main features of our patent law. ${ }^{7}$ Under it an inventor, i.e., one who has developed something not previously known and which is quite out of the ordinary and not likely to be developed in the run-of-the-mine activities of individuals "skilled in the particular art," receives the assignable right to exclude others from the use of his invention for a period of seventeen years from the date when the patent issues. He also receives by implication the correlative right to refrain from excluding others, for instance by licensing them to use the invention. In return, the inventor must make a clear and public disclosure of his invention, thereby enabling other individuals and the public in general to benefit from it, perhaps through stimulation to new ideas from its disclosure and in any event by use of the invention after the patent expires. The patentee must also clearly define the scope of the invention he claims, a necessary requirement to enable the Patent Office to state just what he is getting by his patent and to acquaint others with the exact boundaries of the field to which the "no trespass" sign applies. To give teeth to the right to exclude, the law permits the patentee to enjoin the use of his invention by those not authorized by him to use it, to sue for damages just as one might sue any trespasser upon one's property, and to treat the unauthorized user as a "constructive trustee" and compel him to account for the benefits he has received from his improper use of the invention. ${ }^{8}$

Patents are not obtainable as a matter of course. The applicant must present his invention to the Patent Office, satisfy that office that it is indeed an invention, that he has adequately disclosed it, and that he has clearly marked out the area in which he asserts exclusive rights. If he does not satisfy the Patent Office, the application is denied without being disclosed to the public and everyone is in the same position as before. ${ }^{9}$ If the Patent Office is satisfied, the inventor gets his patent. It does not follow that it is a good patent. Under the law it is merely prima facie valid and is subject to attack in the courts on numerous grounds. ${ }^{10}$ Thus, the final decision as to whether an inventor is entitled to his seventeen years' right is made by the courts -if the issue ever reaches the courts on the merits. ${ }^{11}$

"It has properly been pointed out that "the patent law is not the same thing as the patent system." Kahn, Fundamental Deficiencies of the American Patent Law, 30 Am. Econ. Rev. 475 (I940). Later discussion, wherein will be noted some of the divergences between the patent law on the books and the patent law in action, will serve to underline this observation.

${ }^{8}$ The right to an accounting for profits has been severely limited by recent legislation, Act of Aug. I, 1946 , c. 726,60 SrAT. 778,35 U. S. C. A. $\$ 70$ (Supp. 1946), which limits recovery to a reasonable royalty, plus whatever special damages can be shown. Thus, the distinction, hitherto important, between damages collectible at law and an accounting in equity largely disappears.

- There are various statutory provisions for review of a Patent Office rejection which are not important to the present discussion.

${ }^{10}$ Rev. Strit. $\$ 4920$ (1875), as amended, 35 U. S. C. $\$ 69$ (1940).

${ }^{12}$ Most patents never get into litigation, either because they are not infringed, because the patentee does not attempt to enforce them against infringers, or because settlements are reached with users and would-be users by the grant of licenses or other means. In some instances even where patents are in litigation determination on the merits is foreclosed, e.g., where licensees or assignors of patents attempt to challenge their validity. Kinsman v. Parkhurst, I8 How. 289 (U. S. 1855). This doctrine of estoppel has, however, been subject to considerable qualification in recent years. Sola Electric Co. v. Jefferson Elec. Co., 317 U. S. I73 (1942); Scott Paper Co. v. Marcalus Mfg. Co., 326 U. S. 249 (I945); 
So much for our patent laws as they appear on the books. Turning again to the public interest aspect, just what does our patent system accomplish? A number of considerations may be urged in its support:

I. By holding out the reward of a seventeen-year exclusive right, it induces research and stimulates ingenuity, which result in the creation of new devices and the development of many ideas which would not have been created or developed but for this hope of reward.

2. By offering a seventeen-year exclusive right, it induces individuals who have made important discoveries to disclose them to the public, thus enabling the public, after seventeen more or less lean years, to make free use of something of which it might never have learned had not the inventor been induced to disclose his secretthe contract theory.

3. It represents a bounty or a bonus paid by a grateful public, i.e., government, for a valuable contribution-the reward theory. This is an interesting and certainly a commendable approach, but one may legitimately question whether it is a factor that carries much weight. Unfortunately, society as represented by government tends to be somewhat niggardly in granting, after the fact, substantial rewards to its benefactors. ${ }^{12}$

4. It gives to an inventor, as a matter of justice, sound public policy, and, perhaps, natural right, the fruits of his own labor and protects from piracy that which he has accomplished..$^{13}$ As one writer has expressed it:

... all the citizen's fundamental personal rights represent simply the State's promise to exclude other persons from the thing which is the object of the right, $i$. e., a grant of a monopoly of use of the thing; ... the rights of industrial and intellectual property (patent rights and trade-marks) are herein no different from the other rights; ...

The social merit at the basis of this right is the general conviction that such invention deserves firm encouragement. But, once the right is so recognized, it is no different in

MacGregor v. Westinghouse Elec. \& Mfg. Co., 329 U. S. 402 (1947); Edw. Katzinger Co. v. Chicago Metallic Mfg. Co., 329 U. S. 394 (I947); cf. United States v. U. S. Gypsum Co., 53 F. Supp. 889 (D.D.C. T943).

${ }_{12}$ Individuals are more likely to give vent to the instinct of gratitude than governments, which, after all, are dealing with the belongings of the people, not their own, and are in a less favorable position to indulge in generosity. Likewise democratic governments, accountable to the people, may find such acts more difficult than authoritarian rulers who can indulge their favorites at their subjects' expense with a certain amount of impunity, for the time being at least." Even the soldier's bonus, apart from its vote-getting aspect, may result only partly from a desire to reward those who have made sacrificesand partly from a feeling that the grant of a bonus at this time will be helpful in inducing support for future wars because of the future soldier's fair assumption that he will also be dealt with generously. $C f$. the "Veterans of Future Wars" of a few years back.

${ }^{13}$ Fox, op. cit. suprap, note 3 , at I4; Stephen P. Ladas, The International Protection of IndusTrual Property, 4-6 (I930); United States v. Parker-Rust-Proof Co., 6I F. Supp. 805, 812 (E. D. Mich. 1945). There is little to suggest that the framers of the Constitution viewed patent rights as a natural right, however, nowwithstanding the constitutional provision is framed in terms of exclusive rights. In the first place, the constitutional provision is merely permissive; it does not require protection for inventions. Secondly, the concept of an inherent right in industrial property has had little currency until fairly recently. In earlier days the more commonly accepted view was that monopolies, for invention or otherwise, impinged upon certain natural rights. I RoBINson on PATENTs 37-52 (1890); cf. Kahn, Fundamental Deficiencies of the American Patent Law, 30 Ax. Econ. Rev. 475, at 476. 
nature from the fundamental rights of property, personal security, and domestic relations, $\ldots 1^{14}$

5. It induces the importation from foreign lands of techniques and ideas which would otherwise not become available. This justification, highly important in the early days when transportation was difficult, when foreigners were looked upon with even more suspicion than they are today, and when the general communication of ideas was almost impossible, is now a negligible factor, although certain vestiges of the concept still remain in some patent systems. ${ }^{15}$

6. The grant of an exclusive right, by depriving others of the right to use the invention, stimulates them to added ingenuity and research in an attempt to "invent around" it, thus creating new inventions which cumulatively add substantially to our total technological knowledge. ${ }^{16}$ Or, what to some extent amounts to the same thing, it may induce one to undertake research for fear a competitor may do it if he does not and thus "block" him off."

7. The development and disclosure of an invention starts a chain reaction. Others learn of the idea through the patent disclosure and are sparked to additional ideas. Thus, a single invention may eventually result in numerous additional inventions.

8. Finally, and of major importance, the patent system, by providing seventeen years' exclusive rights, encourages the exploitation and commercial development of the invention. An invention is necessarily new and untried. If it is a product, the public may not take to it. If it is a process or machine, it may not work in practice, at least without substantial and expensive modification, however practical it appeared on paper and however successful the experimental and laboratory tests. In short, it is often a long step from creation of the invention itself to actual availability of its benefits to the public, a step that may be attended by considerable investment, additional experimentation, and real possibilities of failure. Speculative efforts call for greater rewards than sure-fire activities. If the developer of an invention must bear the costs of failure alone, but must share its success with others who will adopt the invention once it is proven, incentive to undertake its development may be seriously retarded. Beyond this, in situations in which the entrepreneur must depend upon outside capital rather than his own, denial of a monopoly profit may make it impossible for him to undertake development of the invention, or even to make the invention itself, or to assume the expense of obtaining a patent if he does make it. A further and related benefit which has been suggested is that the organization which possesses a strong patent position, and hence a profitable one, can afford to plow back its profits into additional research and in fact does so, whereas the organization subject to vigorous competition has little in the way of profits to expend on such activities. ${ }^{18}$

14 Wigmore, The Patent "Monopoly," 25 J. PAT. Off. Soc'y 687, at 688, 689 (I943).

${ }^{15}$ Fox, op. cit. supra, note 3 , at 45 .

${ }^{20} \mathrm{Sec}$ testimony of William H. Davis in Hearings before the Special Committee on Atomic Energy on S. 1717, Pt. I, 79th Cong., 2d Sess. 6I-62 (1946).

${ }^{17}$ Frank J. Kottke, Electrical Technology and the Public Interest 45 (I944).

${ }^{18}$ Id. at 124 . 
The justifications enumerated make a strong case indeed for a patent system such as we have, and give support to the claims of those who insist that our patent system, more than any other single factor, is responsible for the amazing commercial and industrial development that has characterized our economic society. But this is only one side of the coin. It is usually true that one does not obtain something without gixing something up. What does the patent system deprive us of?

I. By granting a seventeen-year exclusive right to the fortunate winner of the race, it deprives one who may have independently arrived at the same discovery of the right, sometimes described as a natural right, ${ }^{10}$ to use it himself-a deprivation which is aggravated by the fact that under our law, within limits, the first inventor gets the patent, even though a subsequent inventor may have made the real public contribution in the sense of bringing it more rapidly to completion and making it available for general use.

2. It deprives others of the right to take advantage of and use for their own benefit the contributions and ideas of others. Although this concept conflicts with the concept of protecting the inventor's right to the fruits of his own labor, ${ }^{20}$ it is one which is thoroughly entrenched in our social system. As Judge Learned Hand has said,

One may bestow much labor and ingenuity which inures only to the public benefit; "ideas," for instance, though upon them all civilization is built, may never be "owned." The plain fact is that all of us make greater or lesser contributions which others may use to their own benefit, just as we ourselves constantly draw upon the achievements and thoughts of others and turn them to our own advantage. It is fortunate that this is so, for it is difficult to conceive a workable social system in which every individual could hold to himself his every achievement or levy a toll upon others to the extent that they obtain benefits therefrom. While it may be that disclosed inventions should receive a protection which is denied to innumerable other ideas and thoughts, a sound determination of this issue is more likely to be found by resort to other considerations, not by reliance upon a concept of broad protection of ideas.

3. Thè grant of exclusive rights may have the effect of discouraging rather than encouraging research and inventive activity, since those who are excluded, at least those who invent for profit and their own advantage-and the patent system is clearly designed to attract persons of that temperament-may be indisposed to labor extensively in fields in which they may be unable to operate for a number of years. ${ }^{22}$

\footnotetext{
${ }^{10}$ I Robinson on Patents 45-47 (1890). ${ }^{20}$ See note 13, sispra.

21 R. C. A. Mfg. Co. v. Whiteman, II4 F. 2d 86, 90 (C. C. A. 2 d 1940).

22 This objection may be partially ameliorated by the possibility of the outsider's "inventing around" the patented invention. Unfortunately, this cannot always be done. Even so, research and invention would not suffer if one could be assured that the patentec would dig vigorously in his exclusive ficld, to use Mr. Davis' analogy (note 16 , supra), even though others were excluded. But it sometimes happens that the domain assigned to the patentee for his exclusive digging is larger than he is able or willing to till effectively, despite which he keeps others out. A flourishing crop of inventions will not result under those circumstances.
} 
4. Perhaps the most serious charge directed against our patent system is that it injects into the sound, well-balanced competitive economy to which we are dedicated $^{23}$ an anomalous monopoly situation which carries with it all the undesirable effects normally attributable to an unregulated monopoly. ${ }^{24}$

It may be granted that we do have in our economic structure a number of institutions, e.g., public utilities, which supposedly operate effectively only within a monopolistic framework. We also have activities which supposedly can operate effectively only under government ownership-the public roads, schools, etc. We have situations in which groups are permitted to band together on a quasi-monopoly basis to achieve sufficient strength to meet at the bargaining table those with whom they must bargain-labor unions, cooperative associations, etc. Indeed, as Professor Wigmore and others have pointed out, the ownership of property is itself a monopoly. ${ }^{25}$

The monopolistic power to exclude others from the use of a patented invention does not, however, seem to fall within any of these categories. It usually operates in competitive surroundings and to that extent is likely to have a disrupting and upsetting influence. Furthermore, it is a monopoly which is permitted to operate free of Government control after it is granted. ${ }^{26}$

The foregoing catalogue of the advantages and disadvantages which flow from our patent system makes one thing abundantly clear. The system is neither black nor white. It brings to our economy many and substantial benefits. It also brings serious detriments, disrupting influences, and upsetting features which we should like to eliminate. A proper evaluation of the system cannot ignore the fact that it has these two sides, any more than an employer-employee relationship can be properly evaluated if one looks only to the work the employee performs or only to the wages one must pay him on Saturday night.

The real question is, do we get enough in benefits, i.e., advancement in technology, development and disclosure of inventions, and exploitation of inventions which would otherwise lie dormant, to make the seventeen-year sacrifice worth while? In short, the patent system must be evaluated in terms of the price we pay for what we get. This suggests three fundamental questions:

I. Do we get from the inventor what we pay for? Alternatively, do we sometimes renege on our promise to reward him after he has performed his part of the bargain?

2. Assuming we pay what the patent statutes say we do, i.e., a seventeen-year

${ }^{23}$ Note 6, supra.

${ }^{24}$ See Kahn, loc. cit. supra, note 13 , at 476 :

"The patent law is a method, a means to a socially desired end. To encourage invention, the State grants to the inventor a monopoly right to manufacture, use, and sell his creation. A strange choice of means, it would seem, for a competitive, laissez-faire society. . . ."

${ }^{25}$ Wigmore, loc. cit. supra, note 14 , at 687 .

${ }^{20}$ The early history of monopoly in England shows that whatever public benefit accrued therefrom largely tended to disappear when the monopolies came to be solely the instruments for private benefit and the government which granted them abdicated its responsibility for controlling their use and preventing their abuse. Fox, op. cit. supra, note 2, at 92-93, 125, 136, 185 . 
exclusive right, are we paying too much? Are we paying too little? In other words, could we get substantially the same results for a lower price? ${ }^{27}$ Alternatively, would we get considerably more if we paid more?

3. Is the price we pay limited in fact to a seventeen-year exclusive right or do we pay more than that? Or less than that? ${ }^{28}$

\section{II}

\section{The Contract: Is There Substantial}

Performance on Both Sides?

It will be recalled that the deal between the Government and the patentee is simply this: The Government agrees to give a seventeen-year right to exclude others in exchange for the inventor's public disclosure of his invention. The inventor fails to perform his part ( $I$ ) if he has not made a disclosure of his invention adequate to enable others to practice it when his exclusive rights expire, or (2) if the device upon which he gets a patent is not in fact a patentable invention. The Government fails to perform its part if it induces such disclosure and thereafter refuses to lend its support to the enforcement of the exclusive right.

Looking first to the question of adequate disclosure, it is apparent that many issued patents do not adequately explain the invention, at least to the extent of enabling others to use it effectively. The numerous court decisions holding patents invalid for this reason bear witness to this. ${ }^{29}$ The importance attached to the furnishing of "know-how" in licensing agreements testifies to it. Situations have occasionally arisen which drive home the inadequacy of patent disclosures. Thus, when the Government took over the German aniline dye patents in the first World War it found that it was impossible to exploit the processes successfully without conducting extensive additional research. ${ }^{30}$

In fairness to the inventor, however, it may be suggested that in many instances the situation is more irritating than serious. The patent law, after all, does not require the disclosure of every possible detail concerning the invention and its use. It merely requires a disclosure sufficient "to enable any person skilled in the art .. to make, construct, compound, and use the same."31 If this standard is met, it cannot be said that the patentee has not fulfilled his obligation or made a contribution. By hypothesis, the invention has been publicly disclosed and can be put to use if one is willing to make an effort. All that can be said against the patentee is that he has contributed less than he could have contributed.

${ }^{27}$ It would seem a fair assumption that in the patent field no social problem arises, as it does in the field of labor, for instance, whereby it becomes necessary in the public interest to guarantee a certain minimum return for one's services, even though those services could be obtained for less if the forces of competition and bargaining were given free play.

${ }_{28}$ The ensuing discussion does not answer these questions. It merely raises them and claborates upon them. Nevertheless it may be useful to arrive at an understanding of what the issues are.

${ }_{20}$ 50 Fed. Digest (Patents) \$II8 (I94I).

${ }^{30}$ United States v. Chemical Foundation, 294 Fed. 300, 318-3r9 (D. C. Del. I924); 5 F. 2d I91, 212 (C. C. A. 3d I925).

${ }^{31}$ Rev. STAT. $\$ 4888$ (I875), as amended, 35 U. S. C. $\$ 33$ (I940). 
The more serious problem results from the granting of patents on developments which purport to be inventions but which do not, in fact, meet the tests of invention as laid down by the courts. Whether or not the courts have themselves erred in their definition of "invention" and their administration of the tests of invention they have laid down, is a question which will be taken up later. For the purpose of the immediate discussion, assume that under our patent laws "invention" is a prerequisite to a valid patent and that the tests of invention adopted by the courts are correct and correctly applied. From the legalistic standpoint, the assumption is a proper one. The courts have the last say as to whether or not a patent should have issued, and if, by their tests, a patent is granted which should not have been granted, the patentee, to the extent that he is successful in enforcing his patent, gets paid without performing his part of the contract, i.e., disclosure of an invention. ${ }^{32}$ From the broader standpoint of the public interest, the picture is a little different. Here, the correctness of the "invention" test and its application cannot be ignored. In other words, if the courts have set their sights too high and have invalidated patents that should have been held valid, one cannot properly accuse the patentee of not performing his part of the bargain. Conversely, if they have upheld patents that should have been invalidated, the problem being discussed is aggravated.

If we accept as correct the standards applied by the courts, the number of spurious patents issued by the Patent Office has been so large as to arouse much discussion and serious concern. ${ }^{33}$ The difficulty arises mainly as a result of the difference between the standards of invention applied by the Patent Office and those applied by the courts. ${ }^{34}$ Even if the standards were the same, the fact that Patent Office proceedings are $e x$ parte in nature makes it unlikely that the full facts and implications of the prior art, on the basis of which the question of invention must be determined, will be brought out. ${ }^{35}$ In the courts, on the other hand, an infringer plays a vigorous role as an opposition party.

${ }^{32} \mathrm{I}$ intend no suggestion of improper conduct in one's inducing the Patent Office to issue a patent which should not have issued for want of invention. What constitutes an invention is a notoriously uncertain question and an applicant is entitled to present his case in the best possible light, provided he acts in good faith and does not mislead the Patent Office or conceal pertinent facts. It is up to the Patent Office to find non-invention if there is none.

${ }^{33}$ Evans, Disposition of Patent Cases by the Courts, 24 J. PAr. OfF. Soc'y 19 (1942); Brown, Developments in the Patent Law as Affected by Adjudications, 22 J. PAT. OfF. Soc'y 587 (1940); Fox, op. cit. suspra, note 3 , at 265-266.

at Compare the following expressions of the Supreme Court and the Court of Customs and Patent Appeals, respectively:

"... the new device, however useful it may be, must reveal the flash of creative genius, not merely the skill of the calling. It it fails, it has not established its right to a private grant on the public domain." Cuno Engineering Corp. v. Automatic Devices Corp., 314 U. S. 84, at 91 (I94I).

". . . until Congress shall otherwise legislate, or the Supreme Court shall otherwise specifically hold, this court will continue to hold that if a process or thing constitutes patentable subject matter, is new and useful, and the process performed or thing produced would not be obvious to one skilled in the art, invention should be presumed and a patent may properly issue therefor." In re Shortell, I 42 F. $2 d$ 292, 296 (C. C. P. A. 1944).

${ }^{35}$ Nor can one overlook the possible impact of the Patent Office review procedure. Considering the numerous opportunities for appeal afforded a rejected applicant, there may sometimes be a temptation to allow the patent in a doubtul case and have done with it. 
Theoretically, the existence of a horde of spurious patents presents no serious problem. The error can be corrected by in infringer's going into court and demonstrating the invalidity of the patent, whereupon the court will declare it unenforceable. Unfortunately, the problem is not that simple. Patent litigation is notoriously expensive, complicated, cumbersome, and slow. It is little satisfaction to an "infringer" of an invalid patent to prove that he had a right to use the "invention" if he has been ruined, or almost ruined, in the process of proving it. In these circumstances, a patent may constitute a powerful coercive weapon for a long period before the courts get around to taking the weapon away.

The combination of these two deficiencies in our patent system, i.e., the existence of a large number of spurious patents and the practical difficulty of demonstrating their spuriousness, creates a situation that we cannot be complacent about. If issued patents were on the whole valid, cumbersome court proceedings for determing invalidity would not be too serious. Conversely, if court proceedings were simple, expeditious, and inexpensive, error in the issuance of patents could easily be corrected. But the situation, as it now stands, is comparable to that of an oppressed people who can obtain no redress for their injuries.

It is not within the scope of this paper to discuss in detail the possible remedies for this situation. Measures which have been suggested for reducing the number of invalid patents issued include the following:

I. More complete access to, and better organization of, scientific treatises and technological information, from which can be obtained a better understanding of the relation between the alleged invention and the art to which it relates. ${ }^{30}$

2. Opposition proceedings whereby others could urge that the patent be withheld. $^{37}$ Whether such opposition proceedings were provided for prior to or subsequent to the issuance of a patent would not seem very important. What is more important is that such procedure implies a departure from the present practice of keeping applications secret until a patent issues-an implication which is probably a little disturbing to those who adhere to the "consideration for disclosure" theory of patents.

3. Proceedings brought by the Government to cancel for invalidity ${ }^{38}$ There is probably little basic difference between this and the opposition proposal, except that the Government instead of a private person assumes the effort and expense of the proceeding-fair enough, perhaps, since the Government was the original sinner in issuing the patent.

4. One device often suggested is simply to eliminate invention as a test of valid-

${ }^{36}$ RePORT OF THE SCIENCE ADVISORY BoARD (1935), in Hearings before the TNEC, Pt. 3, 76th Cong., Ist Sess. II39, II 45 (1939); Hearings before the Committee on Patents on H. R. 3605, 76th Cong., Ist Sess. (I939); Hearings before the Committee on Patents on H. R. 672I, 76th Cong., Ist Scss. (1939).

${ }^{37}$ RePort of tHe SCIENCe Advisory Board, cited supra, note 36, at II4I; Report of the National Patent Planning Commission II-I2 (I943); H. R: 2660, 80th Cong., ist Sess. (1947).

${ }^{38}$ Note, Patent Validity in Anti-Trust Suits, 42 Cor. L. REv. $1 \times 82$ (I942); of. S. 72, Tit. IV, 8oth Cong., Ist Sess. (I947). 
ity. ${ }^{30}$ This is a simple and certainly effective way of disposing of the problem. But unless it can be justified on public interest grounds, and I have difficulty in seeing how it can be, it is tantamount to preventing crime by repealing the criminal laws.

On the litigation side, the following measures, among others, have been suggested:

I. Creation of a single court of patent appeals, ${ }^{40}$ a device which, whatever its merits in other respects, would probably not go very far toward solving our problem since the main difficulties under discussion here arise at the trial-court level.

2. Referral of validity questions back to the Patent Office for an advisory opinion. ${ }^{41}$

3. Appointment of scientific advisers to aid the judges. ${ }^{42}$ Whatever contributions advisory experts, whether in the Patent Office or specially appointed, may make in obtaining better decisions, it is doubtful whether they would contribute much to expedition and economy in litigation.

It is significant that all three of the above proposals have for their premise that the problems attending patent litigation, especially on the issue of invention, are so complicated, technical, and abstruse that they lie beyond the ken of the ordinary judge engaged in the routine discharge of his duties. In other fields than patents we have met this type of situation, once it became sufficiently acute, by setting up specialized tribunals - tax courts, labor boards, customs courts, workmen's compensation tribunals, Federal Trade Commissions, Interstate Commerce Commissions and so on-tribunals which are still subject to some court control but which take care of a large proportion of the controversies which had previously fallen to the courts. Certainly, the possibilities of a similar approach to the patent question should be investigated. The establishment of such tribunals is, of course, no panacea. Litigation before them can be just as protracted, just as complex, just as expensive as litigation before the courts. Their decisions can be just as erroneous as court decisions. Conceding all this, it is probably a fair deduction that such tribunals have, by and large, helped rather than hindered in the solution of the specialized problems diverted to them.

Thus far, the discussion has been directed to the question whether the public gets what it pays for. What about the patentee?

On the validity issue, he may be injured in two respects: (I) If a court erroneously holds invalid a patent which it should have held valid, he loses the seventeenyear exclusive right which the Congress promised him when it enacted the patent law; (2) in accepting a patent he has given up the right, such at it is, to keep his discovery secret; if the patent is later held invalid he will have disclosed his secret without receiving anything in return.

\footnotetext{
${ }^{30}$ Fox, op. cit. supra, note 3 , at 285-308.

${ }^{40}$ Report of the Science Advisory BoARd, cited sipta, note 36, at II42; Report of the National Patent Planning Commission r6-i7 (I943).

11 Report of the National Patent Planning Commission 15-i6 (i943).

12 Report of tHe ScIence Advisory BoARd, supra, note 36 , at II42-II43; concurring opinion of Judge Frank in Picard v. United Aircraft Corp., I28 F. 2d 632, 639-640, 64I (C. C. A. 2d r942).
} 
I question whether either of these injuries is very serious. As for the first, there is no indication that the courts err any more frequently in applying the tests of invention than they do in applying other legal tests, or that such errors as do occur are more often prejudicial to the patentee than favorable to him. ${ }^{43}$ As for the second, the patentee knew when he accepted the patent that he was runing the risk of its being declared invalid. Furthermore, by hypothesis, he has not lost very much since the very ground upon which it is held invalid is that others would make the "invention" if he did not."

The litigation problem is more serious. The complexities and expense of litigation may be as disadvantageous to the patentee as to the alleged infringer, since a powerful infringing corporation may make it virtually impossible for a patentee without substantial resources to establish the validity and infringement of his patent. Some of our great inventors, who certainly were not less able than the average individual inventor to defend their rights, have testified in vigorous terms to the effect upon inventors of our legal machinery. Thus Thomas Edison:

The long delays and enormous costs incident to the procedure of the courts have been seized upon by capitalists to enable them to acquire inventions for nominal sums that are entirely inadequate to encourage really valuable inventions. The inventor is now a dependent, a hired person to the corporation. The administration of the law is the cause. ${ }^{45}$

And Dr. Baekeland:

Woe, indeed, to the poor inventor who tries to enforce his rights against wealthy infringers, aided by skillful lawyers; his well-engraved United States patent parchment may then become his certificate of entrance to the poorhouse or to the lunatic asylum. All this tends to discourage invention by independent individuals and paralyzes the stimulation of invention our Constitution intended to promote by the patent law. ${ }^{48}$

There is little to indicate that there has been much change in the situation since these statements were made thirty-five years ago. A recent commentary has the same familiar ring:

... infringement litigation, lasting many years and costing many thousands of dollars, is necessary in order to test the validity of the disputed patent and to determine whether infringement has occurred. If both parties wish to, and can afford to, they may go through with the litigation until it ends either in a judicial decision or in exhaustion or bankruptcy of one of the parties. If the parties are unable or unwilling to go on,

${ }^{43}$ It is essential to distinguish here between errors in the application of the invention tests and errors in the tests themselves. The validity of the tests of invention is a facet of the issue whether we pay too much or too little for inventions. Knowing that the standard of invention is high and that his patent is only prima facie, not conclusively, valid, the patentee cannot complain if it fails to meet that standard and is adjudicated invalid; he can complain only if it does meet the standard and a court crroncously holds that it does not.

«If, as has sometimes been suggested, all patent applications were made public instead of being retained in secrecy unless or until a patent issues, the patentee whose patent has been declared invalid would be in no worse position than if it had been denied at the outset.

${ }^{45}$ Hearings before Committee on Patents on H. R. 23417 (Oldfield bill to revise and codify the Patent statutes), 62d Cong., 2d Sess. Pt. 23, 32 (1912).

${ }^{6}$ Id., Pt. 4 , at 34 . 
they will be forced to settle, or to forget the whole matter, thus rendering questions of iustice quite irrelevant and making questions of relative strength and bargaining power the major determinants of the outcome. The patentee needs money to protect his rights -rights which, after years of litigation, he may find to be non-existent. No wonder he so often gives up the patent for little or nothing to others who can afford the luxury of owning it and enforcing it in the courts. ... 47

In short, the present situation plays into the hands of the litigant with the strongest financial backing and the litigant who has an interest in maintaining the status quo, whether he be the one who is attempting to enforce the patent or the alleged infringer. This particular defect operates indiscriminately upon small patentee and small infringer alike. It may be true, as pointed out before, that its adverse effect on the infringer is more serious than upon the patentee because of the many spurious patents outstanding. But this is small comfort to the patentee who does own a valid patent which should give him enforceable rights but which turns out to be, as Dr. Baekeland says, "his certificate of entrance to the poorhouse or to the lunatic asylum."

\section{III}

\section{The Reward: Do We Pay the Right Price for Invention?}

For the purpose of inquiring whether we pay too much or too little for invention, I will assume we pay what the patent law says we pay: the grant of a seventeen-year right to exclude others from practicing it. The issue is to be tested by asking several questions: Is it necessary to give exclusive rights? Might we achieve adequate invention and exploitation by limiting the inventor to collecting a royalty for the use of his invention, at least for some part of the period or with respect to certain uses? Is a seventeen-year patent needed to induce adequate research and exploitation? Should the period be even longer? Or might it be made shorter and still accomplish our objective? Could the scope of patent protection, represented by the claims of the patent, be narrowed, thus reducing the area in which the inventor has exclusive rights? Should its scope be enlarged? Finally, might the standard of invention be made even higher than it now is, thereby limiting the patent grants to only the most outstanding "inventions"? Or should the standard be lowered?

As a general proposition, the more we offer to pay for invention the more invention we are likely to get. ${ }^{48}$ If this were the sole issue, the answer would be simple: give more rights and get more invention. But the answer is not that simple. As in other fields, there is a point of diminishing returns, when the extra contributions we get are not worth the price we pay. Thus, increased efforts in utilitarian research, the type brought forth by the patent system, may result in lessened activity in other fields equally or more important from the broad social standpoint. Even

${ }^{47} \mathrm{Kahn}$, loc. cit. supra, note $\mathrm{I} 3$, at 484 (1940); see also, Picard v. United Aircraft Corp., supra, note 42 , at $64 \mathrm{x}-642$.

${ }^{48}$ This is subject to some qualification when inventions culminate in patents. The issuance of a patent may discourage rather than encourage research by others if it blocks off a field of endeavor. Similarly, it may block, and thereby discourage or prevent, the exploitation of inventions. 
within the field of technology itself, the stimulus of our patent system may divert individuals from fundamental and basic research into petty gadgeteering. These questions aside, the question still remains whether, considering modern business, industrial, and commercial circumstances, it might not be possible to reduce the reward substantially without reducing to any great extent the incentive to invent and exploit.

Turning first to the question of the exclusiveness of the grant and viewing it from the standpoint of the stimulus to invent: Notwithstanding the frequent assertion that exclusiveness is the very heart of the patent system, it is doubtful whether this feature is a sine qua non of the stimulus to invent. The evidence suggests the contrary. Much research is carried on by organizations which do not themselves exploit the patents they obtain but license them on a royalty basis instead. Much research is carried on, especially in educational institutions, without the expectation of any return at all for the inventive effort other than the credit and acknowledgment that is extended to successful effort. The inventor himself-and invention in the last analysis is the product of personal effort-is rarely compensated in terms of exclusive rights; rather he receives a salary or bonus for his contribution, with the execlusive rights going to his employer.

Outside the patent field, there is ample evidence of a willingness to undertake given activities, provided a fee is forthcoming from those who benefit. The same type of reward should be adequate to stimulate invention. Most countries have compulsory licensing laws, at least of a limited nature, and I am not aware that their existence has substantially discouraged invention. Within our own system compulsory licensing operates to a limited degree with respect to production or use by or for the Government. ${ }^{49}$

Direct stimulus of invention, however, is not the whole answer. Indirectly, exclusiveness may encourage research by compelling individuals to "invent around" patents. Whether this advantage is sufficiently important to offset the substantial disadvantages that arise from denying others the opportunity to use an invention, even though they are willing to pay a toll for the privilege of doing so, is far from certain.

The case for exclusiveness on the ground that an exclusive period is necessary to attract capital and induce exploitation of the invention is on firmer ground. Some enterprises based upon new inventions may be quite speculative and uncertain, involving the production of goods which the public may reject for lack of utility or for other reasons. Conceding that this is sometimes true, it hardly affords adequate justification for the grant of exclusiveness in those situations-perhaps the more typical ones-in which it is apparent that the article to be produced will find ready acceptance with the public, or where little initial investment is required and hence the need for holding out additional reward is slight.

It is also urged that exclusiveness is necessary in order to enable the small be-

${ }^{40} 36$ STAT. 851 (r910), as amended, 35 U. S. C. $\$ 68$ (1940). 
ginner to protect himself against well-established competitors until his infant business reaches a point where it can stand on its own feet. No doubt this is sometimes true. There is only one hitch. Modern research has become increasingly a bigbusiness activity. More and more patents come to rest in the hands of large companies. One may at least inquire whether the du Ponts, the General Electrics and the R.C.A.'s need patent protection against the small, scattered, individual enterprises, however much the reverse may be true. The "protection" argument is further weakened by the fact already mentioned that a patent may be a powerful weapon if one can spend the money necessary to enforce it and a relatively ineffectual weapon if that money is lacking. ${ }^{50}$

Issues similar or comparable to those just discussed come up in connection with certain other features of patent protection. Thus, one can evaluate the seventeenyear period of protection only in the light of whether a longer period would give a fillip to the inventor which would bring forth enough additional research, or whether it would induce sufficient additional exploitation which would not be forthcoming under a mere seventeen-year monopoly, to justify depriving the public of the free use of the invention for the additional period. Conversely, could the period be cut down, with consequent advantage to our competitive society, without putting much of a damper on either the stimulus to invent or the incentive to exploit? I do not answer the question. I merely pose it. There appears to be little suggestion, however, that the present period is too short. The exceptions are largely limited to individual cases in which Congressional extension of specific patents is sought (almost always unsuccessfully), ${ }^{51}$ proposals for the extension of certain classes of patents because circumstances, usually war, have interfered with their exploitation, ${ }^{\mathbf{5 2}}$ and the uncritical suggestions of some commentators that patents should receive protection for periods comparable to those given to copyrights and trade-marks. On the other side, it may be pointed out that in this fast-moving world seventeen years is a long time. It has been suggested that in today's economy the seventeenyear grant is both unnecessary and undesirable. ${ }^{53}$

${ }^{60}$ The tendency to argue broad principles (of which this article is an example), rather than look to actual facts, finds illustration in this connection. Despite the violent controversy as to whether the patent system protects or injures small business, no one, as far as I know, has taken the trouble to examine the patent cases to ascertain the extent to which big companies have been successful in patent litigation as compared with small companies. Such a study would not, of course, provide a complete picture, since many patent controversies are settled without resort to litigation-usually, it has been suggested, to the relative advantage of the big company. KoTTKE, op. cit. supra, note I7, at I34-I35.

${ }^{61}$ But see Priv. L. No. 554, 58 STAT. 1095 (1944), extending the Aronson patent.

Es Act of May 3I, r928, 45 StAT. Ior2-ror 4 (I928), 35 U. S. C. $\$ \$ 40(a)-40$ (d) (I940); see H. R. 65, H. R. 124, H. R. 1107, and H. R. 1984, 80th Cong., Ist Sess. (1947).

"s "Technology moves now with a speed once undreamed of-its swift march dictates a shortening of the life of a patent. Industries move at very different tempos-unlikeness suggests life spans accommodated to their distinctive requirements. The patent system itself is not designed to give protection at all points where creation touches the industrial arts; if it is to fit neatly, its life span needs to be measured to a variable necessity. A news agency requires protection for its coverage for 4 hours. The life of a design in a dress is a season; its protection for a few weeks is as much as the designer wants. In radio reception technique moves at a brisk pace; in automobiles, innovation now comes far more rarely; in the sewing machine an industrial art is almost stagnant. The period of privilege 
The extent of patent protection is also susceptible of expansion or contraction by enlarging or narrowing the scope of the claims allowed. The question, again, is whether enlargement is desirable in the public interest to encourage research and exploitation or whether the scope of protection could be made narrower than it now is without unduly retarding the progress of science and useful arts. Theoretically, one receives protection coextensive with the scope of one's invention, and there would seem little room for flexibility on this score. As a practical matter, however, there is room for considerable discretion both in formulating allowable claims and in interpreting them. As will be seen later, the courts in interpreting claims and passing upon their validity have injected considerable flexibility into an otherwise quite inflexible system.

The question whether the standards of invention should be higher or lower than they now are involves a number of special considerations distinct from those that arise in the more obvious matters just discussed. Here, as in the previous discussion, the issue is whether the public interest calls for a higher test of invention, resulting in fewer patent monopolies but perhaps less incentive to invent and exploit, or a lower test, resulting in more patents and more incentive. Probably no phase of the patent system has been the subject of more controversy, and more broken lances, than "invention."

It would help in evaluating this point if we knew what the present tests are. We know what seventeen years means. We do not know what "invention" means. Numerous and varied tests have been conjured with by the courts and the Patent Office. Rules of thumb have been applied and, almost as frequently, ignored, such as the rules that mere addition or subtraction of elements, mere aggregation as distinguished from combination, changes in form, reversal of parts, substitution of elements, etc., do not constitute invention. ${ }^{54}$ Other affirmative tests, such as satisfaction of a long-felt want, delay in achieving success despite long efforts, contribution to society, extent of commercial success, extent of research necessary, and so on, have been applied or suggested as tests to determine whether a given result is relatively difficult to achieve and/or sufficiently beyond the ken and ingenuity of the average man to warrant the title of "invention." In even more generalized terms,

should be long enough to keep invention on the march and short enough to prevent an interest from becoming vested. Upon the current stage, a span of $\mathrm{r}_{7}$ years-fixed when technology moved at a far slower tempo-may be quite excessive. It may well put in jeopardy the very institution of free enterprise to which it was set down as spur and exception. If its prolonged life allows its owner to dig in securely and to rest upon his rights, it fails the office it was intended to serve." WaLton $H$. Haxillton, Patents and Free ENTERPRise 157 (TNEC Monograph 31, 1941).

${ }^{5}$ Knoblock, Patentable Invention, 6 Notre DaMe Law. 225 (1931); Plaisted, What Is Invention? ${ }_{4}$ J. PAT. OfF. Soc'Y 328 (1932).

${ }^{60}$ The following are only a few of the many discussions of the subject: Stringham, Invention, 15 J. PAT. OfF. Soc'y 5 II (1933); Dietrich, $A$ Definition of Invention, 13 id. 595 (1931); Case, A Plea for Equitable Consideration When Trade-Novelty is Established, 15 id. 437 (1933); Hoar, Definition of Invention, $3_{4}$ id. 25 (1932); Seiz, Invention, 1 id. 380 (I919); Mann, Testing for Invention, 15 id. 6 (x933); Root, Lack of Invention as a Ground for Rejection, 21 id. 64 (1939); Dawson, Research as a Criterion of Invention, 29 id. 567 (1947); Allyn, Patentable Yardsticks, 25 id. 791 (1943); Richard, Standards of Invention in the Patent Office as Affected by Recent Decisions, 27 id. 24 (1945); Richey, 
so indefinite as to afford little help as a workable test, invention has been described as "something more than the mere application of mechanical skill," a "flash of genius," "that impalpable something," little to do but throw up one's hands in despair and say that invention, like the Constitution, is what the judges say it is.

The inherent uncertainty in the existing tests of invention has been a crucial problem in the patent system, from the standpoint of both the patentee and the public. The National Patent Planning Commission urged as one of the major reforms the formulation of an objective test of invention. ${ }^{58}$ Legislation to establish such a test has been introduced in Congress. ${ }^{59}$

Unfortunately, there is serious question whether the problem can be solved by the mechanical application of any sort of yardstick. The basic issue facing the courts and the Patent Office, however, is this: Can it be said that the specific "invention" before the tribunal is sufficiently remote from the grasp and understanding of most people that it is reasonable to suppose that it would not have become available to the public but for the increased efforts which the patent system induces, for such a long period of time that it is worth while, from a public standpoint, to give to the inventor the extensive rights which he receives under the patent laws?

Obviously, the criterion just suggested is no more susceptible of mechanical appli-

Some Objective Tests, 27 id. 187 (1945). One of the more illuminating discussions of the real issue, although it offers no solution, is found in Emerson Stringram, Outzine of Patent Law 222-253 (1937).

${ }^{\circ}$ Densmore v. Scofield, I02 U. S. 375, 378 (I880); Cuno Engineering Corp. v. Automatic Devices Corp., $3 I_{4}$ U. S. 84 , 9I (I94I). One federal judge has discovered that, by sticking one's tongue in one's cheek, the flash of genius can be made to work both ways-which should simplify the problem considerably:

"I remember once, in the trial of a patent case, where it was contended with great vigor on the one side that the patent evidenced invention of the highest order, and with equal vigor on the other that the device in question was merely a mechanical advance, I announced, almost without any sense of incongruity, that I would take the case under advisement, and after 'having well and exactly seen and surveyed, overlooked, reviewed, read and read over again' etc., all of the briefs, authorities and the record, would wait awhile before deciding to give my mind a chance to hunch it out, for if there was the flash of invention in the device my mind would give back an answering flash; while if there were none, my mind would, in a dully cogitative way, find mechanical advance." Hutcheson, The Judgment Intuitive: the Function of the "Hunch" in Judicial Decision, I4 CorN. L. Q. 274, 280 (1929).

${ }_{87} \mathrm{McClain}$ v. Ortmayer, I4I U. S. $4 \mathrm{I} 9,427$ (I89I).

${ }^{68}$ Report of the National Patent Planning Commisston 14-15 (1943).

to H. R. 3694, 79th Cong., Ist Sess. (1945).

${ }^{00}$ The courts have not always been blind to this basic criterion. Thus, in Atlantic Works v. Brady, ro7 U. S. 192, 200 (1882), the court said:

"The design of the patent laws is to seward those who make some substantial discovery or invention, which adds to our knowledge and makes a step in advance in the useful arts. Such inventors are worthy of all favor. It was never the object of those laws to grant a monopoly for every trifling device, every shadow of a shade of an idea, which would naturally and spontaneously occur to any skilled mechanic or operator in the ordinary progress of manufactures. Such an indiscriminate creation of exclusive privileges tends rather to obstruct than to stimulate invention. It creates a class of speculative schemers who make it their business to watch the advancing wave of improvement, and gather its foam in the form of patented monopolies, which enable them to lay a heavy tax upon the industry of the country, without contributing anything to the real advancement of the arts. It embarrasses the honest pursuit of business with fears and apprehensions of concealed liens and unknown liabilities to lawsuits and vexatious accountings for profits made in good faith." 
cation than the "flash of genius" test. It does have the merit, however, of focusing attention on the fundamental issue involved, and to that extent has some advantage over meaningless rules of thumb and mystical catch phrases.

Even as a broad criterion, however, it requires considerable qualification and elaboration. Thus, one cannot overlook the fact that not only stimulus to invent, but inducement to invest and exploit are important considerations; ${ }^{61}$ that a successful patent must not only pay for itself, but must pay for the many failures in inventive effort-in other words, that the speculative nature of inventive activity may call for a higher reward than would be needed for an activity in which success is assured; that once the invention is made, the public will not necessarily be deprived of the full benefits therefrom for seventeen years, since the inventor may exploit it abundantly himself, license others to do so, or infringers may exploit it if the inventor does not; that the patent may be held invalid, opening up the invention to all who wish to use it. Aside from actual exploitation, the disclosure is useful in itself since it may stimulate others to activity in the same field. ${ }^{62}$

There are still further qualifications to be considered. In many situations we grant patents to individuals even though it is perfectly clear that the invention could be obtained for nothing; e.g., where it has been disclosed and published before a patent issues, where it has been patented in a foreign country, where another person makes the invention about the same time and either abandons it to the public or is barred for some reason from obtaining a patent. In such situations, we grant patents notwithstanding the availability of the invention, and it is proper that we do so since we have promised that we would. For that matter, in many of these situations the disclosure of the invention prior to patenting might not have occurred but for the fact that a patent would be forthcoming anyway. This will often be true where the applicant himself makes the disclosure. The simultaneous inventor may himself have been stimulated to invent by the hope of obtaining a patent. The foreign inventor may have been stimulated to invent there because he could obtain a patent in the United States.

Finally, one cannot ignore entirely the "reward" concept, even though the stimulus theory is the one upon which we probably should, and do, rely most in justifying and evaluating the patent system. If one has made a great contribution to the public good there is certainly nothing wrong in paying him for it, even though he was not induced to do so in the slightest by promises held out to him in the form of

\footnotetext{
${ }^{\text {e1 }}$ Judge Frank suggests that today exploitation may overshadow research and invention as the ob. jective to be achieved through the patent laws:

"The controversy between the defenders and assailants of our patent system may be about a false issue-the stimulus to invention. The real issue may be the stimulus to investment. . ." Picard v. United Aircraft Corp., supra, note 43 , at 643.

${ }^{62}$ On the other hand, it must be recognized that frequently the upsetting effect of the patent monopoly does not cease with the expiration of the patent and the end of seventeen years. This aspoct of the problem will be discussed later.
} 
patent protection and even though he came by the idea with little effort or sacrifice on his part. ${ }^{63}$

Granting all these qualifications, it still remains true that the seventeen-year exclusive right which a patent gives is a high price to pay. It should be paid only for noteworthy, not trivial, contributions. Beyond this, even where the contribution is substantial that very fact may result in the payment of a price greater than should be paid, since the patent laws contemplate that the scope of patent protection shall be coextensive with the scope of the invention.

Although the courts are disposed to assign more or less technical reasons for their decisions in this field, it may well be that many of their decisions holding patents invalid or narrowing their scope really reflect an application of these principles. This may explain their insistence upon a high standard of invention as well as their refusal to sustain claims of extremely broad scope ${ }^{64}$ and their limitation of the patentee to devices actually disclosed in his patent even though the invention he made, and claimed, goes farther. ${ }^{65}$

Unfortunately, except where a patent grant can be broadened or narrowed by judicial construction of its claims, the courts are compelled to decide cases on an "all or nothing" basis. They have no choice except to give the patentee a great deal or nothing at all. This is satisfactory enough in the occasional black and white cases. It is not satisfactory in the much more common gray cases. Having before it an invention that merits some reward, but not a seventeen-year exclusive right, the court must either award the patentee nothing or give him too much. The Patent Office is faced with the same problem. As a rough generalization, it may be said that the courts today tend to meet that dilemma by holding the patent invalid, thereby protecting the public but injuring the patentee. The Patent Office tends to meet it by allowing the patent to issue, thereby protecting the inventor but injuring the public.

Neither the courts nor the Patent Office is to blame for this unsatisfactory situation. The fault lies in the patent laws themselves-in the inflexibility and rigidity of our "one-price" patent system, wherein we offer exactly the same reward to all inventors irrespective of the extent of their contributions, ${ }^{66}$ the amount of stimulus

${ }^{03}$ The "flash of genius" concept, if taken literally, is consistent with the "reward" theory, but not with the "stimulus" theory. Presumably, "llashes" do not result from hard work, extensive experiment, costly trial and error. They just happen-and probably would happen even if there were no patent to be obtained. The patent system may be the spark that sets off rescarch effort and exploitation, but I doubt if it is the spark that sets off a "flash of genius."

${ }^{04}$ O'Reilly v. Morse, ${ }_{15}$ How, 402 (U. S. 1853 ).

${ }^{\circ o}$ Halliburton Co. v. Walker, 329 U. S. I (1946).

${ }^{60}$ In one sense, $i$. e., in terms of the actual reward which one receives from a patent, there is a great deal of flexibility. The system is well designed to encourage effort in the fields of greatest commercial and industrial importance and discourage it in unimportant fields, by providing for a generous reward for useful inventions and a niggardly reward for those that are not useful. As one court has stated it:

"Whether it be more or less useful is a circumstance very material to the interests of the patentee, but of no importance to the public. If it be not extensively useful it will silently sink into contempt and disregard." Lowell v. Lewis, 15 Fed. Cas. I018, No. 8568 (C. C. Mass. I817).

This, however, is no answer to the problem under discussion, i.e., how to obtain needed flexibility 
needed to induce invention, or the stimulus needed to achieve exploitation. Some inventions are achieved only through extensive expenditures of time, capital and ingenuity; others may flash across one's mind and be reduced to paper at almost no cost. Some inventions require substantial capital outlay for exploitation, additional experiments and research, extensive and expensive efforts to convince the public that the new device is something it wants. Others can be tried and dropped, if they prove to be failures, without loss of time or money. Successful exploitation of some inventions is apparent from the start. The success of others is highly conjectural.

Despite these variations, we still give the same reward to all. A system in which every worker receives, say, ten dollars a day, irrespective of whether he is a college graduate or an illiterate, capable of a hard day's work or a weakling, industrious or one who soldiers on the job, would run into serious difficulties.

It is easy to point out the fault of rigidity and inflexibility. It is harder to suggest remedies. Obviously, each invention cannot be evaluated in terms of what reward was necessary in order to bring it forth and what stimulus will be needed to bring it into use, and a patent issued on that basis. Nevertheless, certain ways of achieving flexibility suggest themselves. - The grant of "petty patents," comparable to the German Gebrauchsmuster, is one that has frequently been mentioned. The effect of this would be to enable those who had made some contribution, but not very much, to obtain some reward and thereby avoid the present situation wherein these borderline inventors get either far more than they should receive or nothing at all.

Other possibilities might include the intentional narrowing of claims to less than the actual scope of the invention, the denial of a right to injunction in some situations, and the use in appropriate cases of government subsidies to provide the stimulus to invent and exploit which the patent is supposed to give. ${ }^{67}$

Compulsory licensing, whatever may be said for or against it on other grounds, presents one of the best means of achieving flexibility. Within the limits set by other considerations, such as ability and willingness of the user to pay royalties, a royalty could be made higher or lower depending upon the research effort and expense involved in making the invention. ${ }^{68}$ Similar flexibility is possible in dealing with incentive to exploit. Thus, licenses might be refused entirely, their grant might

in the stimulus to research and exploitation, since there is no necessary correlation between the eventual commercial importance of an "invention" and the efforts that are needed to bring it into bcing and get it into use.

${ }_{67}$ The subsidy, in one form or another, has come in for increasing attention in recent ycars. Busir, SCIENCE the EndLess Frontier (1945); Hearings Before the Committee on Military Affairs on S. 1297, 79th Cong., $2 d$ Sess. (1946); Atomic Energy Act of 1946, note 5, supra; Investigation op Government Patent Practices and Policies, i Rep. AtT'y GeN. 3, 6 (1947); S. 1248, 79th Cong., 2d Sess. (1946).

${ }^{88}$ The Atomic Energy Act of 1946 , supra, note 5, permits consideration of this factor in determining reasonable royalties under patents useful in this field. Section $\operatorname{Ir}(\mathrm{e})(3)(A)$ provides:

"In determining such reasonable royalty fee, the Commission shall take into consideration any defense, general or special, that might be pleaded by a defendant in an action for infringement, the extent to which, if any, such patent was developed through federally financed research, the degree of utility, novelty, and importance of the invention or discovery, and may consider the cost to the ouner of the patent of developing such invention or discovery or acquiring stch patent." (Emphasis supplied.) 60 STAT. 768,42 U. S. C. A. $\$ 181 \mathrm{II}(\mathrm{e})(3)($ A) (Supp. 1946). 
be postponed for a certain number of years, they might be limited in terms or in the number of them issued, or they might be issued to all applicants, depending upon what would best serve the broad public interest from the exploitation and investment standpoint. True, one would not know before the invention was made just what the extent of his reward would be, but one does not know that under the existing system. Nevertheless, if the entrepreneur knew that he would obtain rights which were reasonable and a reward that was fair under the circumstances, who can say that the progress of science and useful arts would not be adequately promoted? In other fields, public utilities for instance, the assurance of a fair and reasonable reward has been a sufficient stimulus to investment.

Thus far, discussion has been limited to the framework of the patent system itself and has ignored the alternative methods of inducing invention and investment. Strong incentives to invent exist other than those stemming from the patent system, some of them having little relation to the matter of material reward. Floyd $\mathrm{L}$. Vaughan, in his Economics of Our Patent System, ${ }^{69}$ lists a number of them: (x) the instinct of contrivance or workmanship; (2) reputation, the desire for fame, and the sense of altruism; (3) division of labor, whereby one's attention is increasingly directed to narrower fields so that one becomes more aware of the problems in the field and more proficient in solving them; (4) intellectual inquiry and curiosity which leads to discoveries; (5) scientific progress, i.e., the cumulative effect of scientific advancement which feeds upon itself and leads, as a matter of course, to further advancement; ${ }^{70}$ (6) divine inspiration; (7) accident; and (8) economic. conditions, i.e., the modern institutions and developments which create a demand for new products and the organization of industry on a basis such that capital and labor can cooperate to supply that demand.

These incentives are by no means the only ones. One cannot ignore the important part that competition plays in inducing invention, provided competitive forces are permitted to come into play. Inherent in the competitive concept is the effort to improve one's product in order to overcome one's competitors and to reduce one's cost of production, not only to maximize profits, but in order to survive. In these efforts research will necessarily be undertaken, at least up to the point where one feels the results are not worth the cost and sometimes beyond that point. ${ }^{71}$

${ }^{\circ 0}$ Pages $I$ to 16 (1925).

${ }^{70} \mathrm{~A}$ refinement of this concept appears in the "invention of invention" theory. ALFRED N. WhItEhead, Science and the Modern World 120-122 (1930); Walter Lippmann, A Prefáce to Morals 232-235 (1929). It was epitomized by Theodore Krebs in Hearings before the TNEC, $\mathrm{Pt}$. 30, 76th Cong., $3 \mathrm{~d}$ Sess. $162 \times 2$ (1940) as follows:

"But after 1850 the progress of science, particularly of the physical sciences, became so systematized that the invention of a product was first blueprinted before realized by processes of deduction and synthesis in the industrial plant."

The implication seems to be that invention is reduced to nothing more than a logical process which anyone skilled in the art can carry through, arriving at an answer as surely as a bookkeeper, given time, can arrive at the total of a column of figures. Its full implications vis a vis the patent system would call for a study of the inventive process and the nature of invention to an extent beyond the scope of this paper.

${ }^{71}$ Factors which may tend to push research beyond the point where it will pay for itself incluaie 
It is not suggested that the stimuli just discussed would completely or even substantially supplant the inducement to invention and exploitation that the patent system offers. Their presence does suggest, however, that even the complete aban. donment of the patent system would still leave us with considerable incentive to invent and exploit.

Accepting the proposition that a direct reward is necessary if the desired degree of invention and exploitation is to be obtained, are there means of obtaining it other than the grant of a seventeen-year exclusive right? The right to a royalty for the use of an invention without the power of exclusion has already been suggested as a possibility which might well provide sufficient incentive and at the same time avoid many of the more serious adverse effects of our present system.

There is also the possibility of subsidy, either for the purpose of stimulating research or for the purpose of exploitation. ${ }^{72}$ Subsidies have always played an important part in our political and economic structure. Government subsidies are not dangerous per se. The danger rather lies in the encroachment by government upon private fields of activity where such encroachment is unnecessary. The question whether government subsidy is necessary or desirable in the field of technology and research is beyond the scope of this paper. ${ }^{73}$ If, however, it be conceded that research is a highly important national resource the development of which is of paramount public interest, it would seem to follow that if that development cannot be obtained through private effort without paying a price that is higher than the public should pay, the Government may, and perhaps should, use its efforts-and the taxpayers' money-to obtain the necessary results at the proper price. On principle it is difficult to see wherein the situation would be different from that which resulted in such activities as operation of the postal system, the public roads, the public schools, the imposition of tariffs, and more recently, aids to private business through RFC loans and support prices. Indeed, the patent system itself may be viewed as akin to a subsidy. ${ }^{74}$ The allowance of tax credit for research expenditures comes even closer.

The foregoing discussion has been directed mainly, although not entirely, to the question of incentives to invent. What about alternative incentives to exploit

(I) the optimism to which the human race is fortunately addicted, (2) pride in one's product, (3) fear of being outstripped by one's competitors, and (4) a tax situation such that a substantial portion of income would be paid to the government in taxes if it were not used instead for research.

${ }^{72}$ Supra, note 67. The Atomic Energy Act of 1946, note 5, supra, presents an interesting experiment in compulsory licensing, subsidy, and payment of compensation by the Government for inventions. See $\$ \S_{3}$ and $I I$.

${ }^{73}$ One thing is clear. One cannot be complacent about a situation in which, notwithstanding the existence of our present patent system for over one hundred years, it has recently been deemed necessary to develop atomic energy under government sponsorship, albeit through private organizations to a large extent, to pass an Atomic Energy Act which contemplates a continuation of such sponsorship, and to pass a National Science Foundation bill (which was vetoed) contemplating government support of research to a far greater extent than in the past.

74 This is clearly borne out when one examines the historical antecedents of our patent system. Patents for invention developed ancillary to a studied and deliberate subsidy policy designed, at least in its origin, to further the public interest. Fox, op. cit. supra, note 3, 188-189. 
inventions, once they are made? Here again, the use of subsidies, to the extent necessary to obtain desirable production in the public interest, provides at least one alternative. Beyond this, one may ask whether it may not be much easier today to induce private enterprise to enter new fields of activity than it was when our patent system was inaugurated and for a long time afterwards. Granting the existence of many bothersome barriers to new business and the continued adherence of private sources of capital to a "safety psychology," the fundamental necessities, barring the temporary problems created by the war, are probably more readily available today than they have ever been before. These include information, technological and other, on how to start and conduct a business; materials; facilities for getting one's product before the public and acquainting the public with it; and the necessary capital, obtainable through government loan if not through private institutions. Finally, developments in labor-saving machinery have created a situation in which we possess a constant oversupply of manpower.

IV

\section{The Real Price We Pay}

$\mathrm{Up}_{\mathrm{p}}$ to this point we have assumed that the price the public pays for an invention is the price which the patent law says we pay, namely, a seventeen-year right to exclude others from making, using and vending. We have seen that, in fact, there may often be some divergence from this standard as a practical matter, sometimes to the public's benefit, sometimes to the patentee's benefit. But granting correct interpretation and adequate disclosure of the invention, availability of remedies and court processes to the would-be users as well as the patentee, and so on, we have assumed that this is the price we pay, and the only price we pay. The remainder of the discussion is addressed to this assumption. Do we in fact give the patentee something more than a seventeen-year monopoly, directly or indirectly? Do we give him less?

In some respects, there is no doubt that we give him less. Most of the ways in which this comes about have already been discussed, such as denying validity to a patent notwithstanding a substantial contribution, unduly narrowing a patent's scope by interpretation, and denying the patentee effective recourse to the courts to prevent or recover for infringement. Beyond this, we may often get something for nothing, simply because the public does not see fit to use the invention during the patent's lifetime. ${ }^{75}$ Patents otherwise valid may be rendered unenforceable as a result of misuse. ${ }^{76}$

${ }^{70}$ Although non-use suggests non-utility in most cases (note 66, supra), this is not always true. Important inventions may be made before their time, with the result that by the time they become really valuable the patent will have expired. Even useless inventions may contain ideas which inspire later developments that prove useful.

${ }^{70}$ Leitch Mfg. Co. v. Barber Co., 302 U. S. 458 (r938); Morton Salt Co. v. G. S. Suppiger Co., 314 U. S. 488 (1942); B. B. Chemical Co. v. Ellis, 314 U. S. 495 (1942); Mercoid Corp. v. MidContinent Invest. Co., 320 U. S. 66I (I944); Mercoid Corp. v. Minneapolis-Honeywell Regulator Co., 320 U. S. 680 (I944); cf. Hartford-Empire Co. v. U. S. 323 U. S. 386 (I945); id., 324 U. S. 570 (I945); United States v. National Lead Co., 67 Sup. Ct. I634 (I947). 
The extent to which a patentee may obtain greater rights than the patent laws ostensibly give him is a more complicated matter. ${ }^{77}$ A given patent, standing alone, is limited to the seventeen-year exclusive right. In practical effect, however, under present methods of operation, a patentee sometimes obtains substantial advantages at the expense of the public which go beyond the scope of his contribution and last much longer than the seventeen years contemplated by the statute. These advantages may arise in three ways: (I) through direct extension of the period of exclusive right beyond seventeen years; (2) through extension of the patent monopoly to cover areas, activities, and fields which lie outside the limits of the patent claims; and (3) through institutional and industrial developments, advantageous to the patentee but detrimental to the public, which may persist long after the patent has expired.

The first category, and probably the least important in actual effect, is illustrated by delay in the issuance of patents. ${ }^{78}$ It is unlikely that many inventors deliberately delay the issuance of patents, and in fact most patents issue within three years after application. Nevertheless, a sufficient number of applications remain pending for five years or more, and extreme cases of flagrant delay involving important patents occur with enough frequency, to make the problem a fairly important one. ${ }^{79}$ In one respect the applicant might be deemed to suffer rather than benefit from this lag, since prior to issuance of the patent others may use the invention with impunity, although it is true that the inventor benefits correspondingly at the other end. On the other hand, the applicant may derive a great benefit through delay in issuance of the patent since others, especially if an extensive investment is involved, will be unlikely to use the invention during the application period, knowing they may be compelled to discontinue use when the patent issues.

The second category involves more serious problems. The efforts of a patentee to extend his monopoly beyond the scope of the patent may take many forms. Although such practices have frequently been held illegal by the courts, they continue to be used and their existence cannot be ignored in determining the price we pay for inventions.

'One of the practices has been the use of the so-called tying clause, whereby the patentee licenses the use of his invention on condition that the licensee use unpatent-

\footnotetext{
${ }^{77}$ Some aspects of this have already been discussed, such as the upholding of patents that should be declared invalid, and denial to the public and "infringers" of effective protection against spurious patents.

${ }^{78}$ Excluded from consideration are those situations in which Congress deliberately extends rights under patents by special legislation. Whether such extensions are justified in the public interest is irrelevant to the present discussion. Act of May 3I, 1928, supra, note 52; 58 STAT. ro95, supra, note 5x.

${ }^{79}$ Hearings before the TNEC, Pt. 3, 76th Cong., 1st Sess. 1132-1135 (1939). The most frequently suggested solution for this problem is enactment of a "twenty-year" law which would limit the patent term to a period of seventeen years from date of issue or twenty years from date of application, whichever is less. Although such legislation has met with general approval, none has yet been enacted. Sce Hearings before the Committee on Patents on H. R. 2361, 79th Cong., 1st Sess. (1945). With limited application, a twenty-year provision is contained in the Boykin Act, which extends the rights of forcigners to 'apply for patents on the basis of prior foreign application. 35 U. S. C. A. \$rro (Supp. 1946).
} 
ed products obtained from him rather than from his competitors. The effect, of course, is a substantial competitive advantage to the patentee in the sale of unpatented goods. The practice has been uniformly condemned as an attempt to use the patent monopoly to control commodities not covered by the patent. It has been held to be contrary to the patent laws, ${ }^{80}$ an abuse of the patent privilege which renders the patent unenforceable until the effects of the abuse are dissipated, ${ }^{81}$ and a violation of the antitrust laws. ${ }^{82}$ Nevertheless the practice still persists.

Another device, somewhat similar to the tying clause, is "package" licensing, i.e., refusal to license one patent unless the licensee accepts licenses under others. The licensee is thus denied the opportunity to accept or reject a given invention. $\mathrm{He}$ is compelled, through his need for one patent right, to pay for other rights which he does not want or which he believes-but cannot asser ${ }^{83}-$ to be invalid. Thus are stopped the mouths of those who may be in the best position to show the invalidity of specific patents, contrary to the public interest in preserving freedom for such a showing. ${ }^{84}$

Another type of tying, commonly used and conducive to the concentration of patents in a single owner, consists of a patentee's requiring, as a condition of licensing, that the licensee assign back the future related inventions he makes. ${ }^{85}$

Improvement patents also become a device for extending one's patent monopoly. True, the original patent expires at the end of seventeen years and is available to anyone who desires to use it. But this is not always sufficient to assure effective competition. Competition, in many fields, is a delicately balanced matter with the advantage going to the one who offers the best product even though its advantage over competitive products may be slight. If a holder of a dominant patent can obtain improvement patents which enable him to continue to put out a better product, after expiration of the basic patent, than his competitors, he may continue to enjoy a substantial competitive advantage, an advantage which is aggravated by his exclusive possession of the field for seventeen years, during which he has established himself on the inside track from the standpoint of goodwill, sales organizations, proficiency and know-how, outlets, etc.

Competitors can, of course, prevent this from happening by conducting vigorous

${ }^{80}$ Carbice Corp. v. American Pats. Development Co., 283 U. S. 27 (1931); Motion Picture Patents Co. v. Universal Film Mfg. Co., 243 U. S. 502 (Igr7).

${ }^{81}$ See cases cited supra, note 76.

${ }^{82}$ International Bus. Machines Co. v. United States, 298 U. S. I3I (I936); Ethyl Gasoline Corp. v. United States, 309 U. S. 436 (1940); Mercoid Corp. v. Minneapolis-Honeywell Reg. Co., 320 U. S. 680 (x944).

${ }^{83}$ United States v. Harvey Steel Co., 196 U. S. 3 Io (r904). Cf. Stentor Elec. Mfg. Co. v. Klaxon Co., II5 F. 2d 268, 272-273 (C. C. A. 3d 1940); Sola Elec. Co. v. Jefferson Co., 317 U. S. I73 (I942); Scott Paper Co. v. Marcalus Co., 326 U. S. 249 (1945); MacGregor v. Westinghouse Elec. \& Mfg. Co., 329 U. S. 402 (1947).

${ }^{86}$ Pope Mfg. Co. v. Gormully, I44 U. S. 224 (I892); Sinclair \& Carroll Co., Inc. v. Interchemical Corp., 325 U. S. 327 ( 1945 ).

${ }_{85}$ The Supreme Court recently held this practice unobjectionable in the absence of a showing of antitrust violation. Transparent-Wrap Mach. Corp. v. Stokes \& Smith Co., 329 U. S. 607 (I947). 
research in the field themselves, looking to the acquisition of improvement patents. But as a practical matter the improvement patents are more likely to be found in the hands of the basic patent owner. This for three reasons. First, the dominant patentee constitutes the most likely market for improvement patents independently developed. Second, as indicated above, he may compel licensees, if he does license, to funnel their improvements into his hands. Third, since he alone is in a position to use improvements immediately, he has a greater interest in conducting research in the field than have his competitors, who must perforce await the expiration of his basic patent before they can use any improvements they develop.

Trade-marks also provide a means for retaining a competitive advantage after patent protection has been lost. A trade-mark attached to a patented article, because it is the only name which the public associates with the article, easily becomes identified with the article itself rather than with its producer. As a result, it may be virtually impossible for others to compete effectively, after the patent expires, unless they can use the same mark. In extreme cases the courts have helped to remedy the situation by declaring such marks to be generic in nature and available for use by all producers of the product. ${ }^{86}$ It has not been suggested, however, that if the patentee takes appropriate measures to maintain his mark as an indication of origin rather than a description of the article he will lose his exclusive right to it. ${ }^{87}$

Yet, even though the mark is preserved as an indication of origin, the tremendous advantages arising out of public familiarity with the mark-advantages which are greatly augmented by the effective and extensive advertising methods of todaymay give the patentee great advantages difficult indeed to overcome. ${ }^{88}$

Trade-mark protection is only one example of the many indirect but highly important competitive advantages that may develop during the seventeen-year period of monopoly. General reputation, development of sales outlets, creation of customer goodwill, the general "know-how" which comes from long operation, all add up to give the patentee an advantage which new competitors in the field may find it difficult, perhaps impossible, to overcome.

The third category, namely, the development of undesirable institutional, commercial, and industrial practices, is the most serious collateral price we pay. These take three main forms: (I) concentration and monopolization of patents in the hands of a single owner; (2) elimination of competition through the division of territories and fields of activity; and (3) the adoption of selective and restrictive

${ }^{80}$ Singer Mfg. Co. v. June Mfg. Co., 163 U. S. 169 ( 1896$)$; Bayer Co., Inc. v. United Drug Co., 272 F. 505 (S. D. N. Y. I92I); Kellogg Co. v. National Biscuit Co., 305 U. S. IrI (1938).

${ }^{87} \mathrm{Cf}$. $\$ \$ \mathrm{I}_{4}(\mathrm{c})$ and $\mathrm{I}_{5}(4)$ of the Lanham Trademark Act, 60 STAT. 433, 15 U. S. C. A. $\$ 51064(\mathrm{c})$ and 1065 (4) (Supp. 1946).

${ }^{88}$ It may be questioned whether the use of a trade-mark with a monopolized article has any place in modern trade. Whatever its original purpose, the trade-mark today is used almost entirely to distinguish one's goods from those of a competitor. Where no competitor exists, does it serve any legitimate purpose? Would it be unreasonable to require that a patentee identify his monopolized product only by its descriptive name and compel him, when his patent expires and competition enters the field, to start from scratch? 
licensing practices which eliminate competition in various ways and set up patterns of non-competition which may continue long after the patents which brought them into being have expired.

The tendency of patents to concentrate in a single owner has already been discussed to some extent. It is necessary here only to reiterate that once a given organization becomes dominant patent-wise in a certain field, the likelihood is great that it will increasingly strengthen its patent position vis a vis its potential competitors through acquisition of other patents, through patents obtained as a result of its own research, or through discouragement of research by others. There may eventually result a tremendous concentration of technology in the hands of a single organization which enables it to render competition completely ineffectual, eliminate competition entirely, or, what is not much better, permit it to exist only by sufferance. Such a result, I suppose, is good enough for those countries dedicated to a system of state monopolies. It is not consistent with our democratic concept of well-balanced competition and free competive enterprise.

Where situations have not reached the point of virtually complete concentration another tendency shows itself, the tendency of powerful organizations which could effectively compete with one another to divide activities or territories among themselves, often on a world-wide basis, each agreeing to keep out of the other's field. Patents often play an important part in such conspiracies. Not only are they frequently used as the colorable justification for the agreements, but they provide a powerful instrument for making them effective. By cross-licensing or crossassigning their respective patent rights, each party to the agreement is provided with a powerful legal weapon, i.e., suit for infringement, by which he is able not only to exclude the other from his assigned territory and thereby force him to abide by the agreement, but also to exclude outsiders who might otherwise intrude and upset the careful scheme of non-competition which has been worked out. ${ }^{89}$

This type of agreement finds its counterpart in the "patent pool," whereby a number of competitors may render their patents available to the respective parties to the agreement. Even where the pool is a so-called "open" one to which any applicant may be admitted, it may have the tendency to cause "rationalization" of an industry rather than competition in it. Where it is a closed pool, i. e., one to which only the favored few or those who are willing to conform to certain policies can gain admittance, these tendencies are aggravated and it is open to the additional objection that it enables a segment of the industry to band together to the detriment of outside competitors.

This is not to suggest that pools should be prohibited. The prevalence of overlapping patents often makes it impossible to use the best technology effectively without impinging upon a number of related patents. Unless the patents happen

\footnotetext{
${ }^{80}$ The practices here discussed are, of course, inconsistent with one of the justifications urged for the patent system, namely, that the grant of exclusive rights will stimulate others to "invent around" the patented invention and thereby achieve furcher technological advance.
} 
to be concentrated in the hands of a single owner, this may mean obtaining the consent of several different patent owners before one is free to go ahead. The patent pool accomplishes a useful purpose in solving this problem. The danger lies in the fact that patent pools, like trade associations, sometimes become diverted from their legitimate and proper purposes into more questionable paths. Technology being what it is, patent pools probably are an essential instrument in today's economy. But, in view of the power that they wield, the choice seems fairly clear: either they must do a thorough job of self-policing or the Government must take on the job of regulating them and their policies to assure that the paramount public interest is promoted, not thwarted.

The third practice which has unfortunate repercussions on our competitive economy is that of selective and restrictive licensing. It is not uncommon for patentees to grant licenses on condition that the licensee adopt certain price policies, limit his production, contain himself within certain territories, abide by specified standards, operate only within certain fields of activity, etc. "While many of the practices in question have been held improper by the courts, they still persist.

Some of these restrictions may be justifiable, if we look at them from the standpoint of the patent laws alone, on the ground that the patentee is merely dividing up his patent and parceling out bits of it to selected individuals. Others, again looking at them from the standpoint of the patent laws alone, have been defended on the ground that the patentee will simply withdraw into his shell and refuse to license altogether unless he can impose them. The merits or weaknesses of these contentions are beyond the scope of this paper. I do point out, however, that the effect of these practices, whether they are justified or not, is to set up a pattern of price control, quality control, and elimination of competition which may become so firmly established during the period the patent is in effect that it will continue to persist long after the patent has expired.90

Further unfortunate possibilities relate to the field of research itself. The day of the garret inventor may well have passed. Research today has become big business, involving extensive and expensive laboratories and large staffs of skilled scientists. It is becoming less and less open to the small businessman. I do not argue the question whether research conducted on this basis is more efficient or achieves greater results in terms of the effort expended than were achieved in the earlier, more individualized, more haphazard types of research. The important fact is that research has, to a large extent, become an activity which is closed to the average man except as an employee of a huge, impersonal organization.

\footnotetext{
${ }^{90}$ Even though the pateatee might retain the field exclusively to himself were he not permitted to license on a restrictive basis, it may be that in some situations the public interest would be better scrved by complete exclusion than by the imperfect competition that results from restrictive licensing. The pattern of non-competition that develops over a number of years may be easier to get rid of if everyone starts from scratch. There would at least be some incentive to infringe (thereby exposing the invalidity of spurious patents) and to "invent around." Finally, depending on the facts, one may ask whether, if we are to be deprived of the benefits which normally flow from competition, we should not at least get such advantages as it is alleged may flow from the concentrated production of the monopolist.
} 
This presents a basic problem. If, as may be true, the big-business type of research is inevitable and if, as may be true, research from now on is to be conducted largely by huge organizations rather than by individuals working in their garages and basements, we must ask whether these research organizations shall be private or public, whether they shall be free to dictate their own policies or subject to some control in the public interest, and whether the public interest can permit them to ally themselves with equally large industrial organizations and to be used as an instrument for the further advantage of the latter.

I do not say how these issues should be determined. I do say they cannot be ignored in arriving at a proper evaluation of the present patent system.

\section{$\mathrm{V}$}

\section{Summary and Conclusion}

The major problems that face the patent system today, and the difficulties that stem from that system and arise to plague the patent owners as well as other members of the public, may be summarized as follows:

r. The "one-price" reward given for patentable inventions, despite the great variations between one "invention" and another in terms of relative contributions and relative expenditures in time, money, and effort, has led to an unsatisfactory situation in which either the public is called upon to pay a high price for a moderate contribution (if the patent is held valid) or the inventor is denied any reward for his contribution (if it is held invalid).

2. The problem has been aggravated by the necessity for relying upon legal procedures that are complex, time-consuming, and expensive, with victory often dependent not on the merits but on one's financial ability to sweat it out.

3. Even where a decision is achieved, supposedly on the merits, the occasional failure of the judge to center his attention on the constitutional objective of the patent system, i.e., the promotion of the progress of science and useful arts, and his resort to meaningless shibboleths and catchwords, makes it a lively question whether the decision will be right or wrong.

4. The foregoing difficulties, all of which go to create uncertainty as to the validity or invalidity of a given patent, are enhanced by the great numbers of patents issued and outstanding, a large proportion of which, because of the lower standards of invention followed by the Patent Office, would be declared invalid if subjected to litigation.

5. Even where a really substantial invention has been made, the question arises whether a seventeen-year exclusive right is not too high a price to pay, considering the greater abundance and availability today, as compared to a time a hundred years ago, of the physical, human, financial, and intellectual materials that are needed to conduct research and start a business; put another way, if less stimulus is needed than in the past to induce research and exploitation, it is improvident not to offer less. 
6. The uses to which patents are put and their effect upon the interplay of competitive forces are quite unlike what they were when the patent system was developed. Whether this is the result of greater concentration of industry, greater interdependence between different segments of industry, greater volume, concentration, or overlapping of patents, or whatever the reason, patents play new and different roles in our economy, even though they may at the same time play the same old role. Their effect must be determined in the light of what they do today, not what they have done in the past.

7. It would appear that research is becoming increasingly a big-business matter, a cooperative or collectivist project. The trend toward concentration of research in the hands of the few means a corresponding or even an increasing trend toward concentration of patents in the same hands. Concentrated patent power, especially when coupled with concentrated industrial power, can become a formidable threat to an economy dedicated to free competitive enterprise unless considerable selfcontrol, or some other less desirable form of control, is exercised.

The plain fact is that our economic society, in which the patent system plays a highly important part, bears little resemblance to the economic society into which that system was born. It is doubtful whether the Founding Fathers, if this is important, ever visualized a situation in which the patent system would be anything other than what it was at that time-a simple device for inducing invention and exploitation at a time when both were difficult and greatly needed in an economy of scarcity, a system under which the patentee would exploit his patent to its fullest advantage through actual production, and with none of the overtones we have today wherein it becomes an instrument which seriously affects entire industries, world activities, and the whole broad competitive economy. It is in its relation to our highly industrialized and complex modern economy of abundance, not in its relation to a simple, largely agrarian economy of scarcity, that the patent system must be examined.

It does not follow, as Judge Hand has suggested, that "perhaps the system is outworn." ${ }^{21}$ And as Judge Frank, and others, have said, "we should not throw out the baby with the bathwater." ${ }^{\prime 2}$ Or, to quote from a level of society somewhat below that of the Circuit Court of Appeals for the Second Circuit, "theres a dance in the old dame yet." W3 What does follow, it would seem, is this: The extent to which our patent system operates for good or evil in our present economy and the extent, if any, to which it should be modified to accomplish the greatest good, and the ways in which it can be adapted to carry out the constitutional purpose and still accommodate itself to the broader and overriding concept of a free competitive enterprise, are matters which cannot be determined by futile references to the past or broad generalities. They can only be determined by hard grubbing into the facts.

${ }^{91}$ Dewey \& Almy Chemical Co. v. Mimex Co., 124 F. 2d 986, 990 (C. C. A. $2 d$ 1942).

22 Picard v. United Aircraft Corp., 128 F. 2d 632, 643 (C. C. A. 2d 1942).

${ }^{93}$ Don Marquis, the lives and times of archy \& mehitabel 26 (1927). 
The most important considerations to which these factual investigations should be directed, in my view, are the following:

To what extent is there a lack of coordination between the reward which is given for an "invention" and the reward that is needed in order to accomplish the constitutional objective of promoting the progress of science and useful arts; and what modifications might be made to achieve a closer coordination and greater flexibility than now exists?

Is the right to exclude a sine qua non of an effective patent system or are there alternative rewards which will provide adequate inducement for invention and exploitation and still avoid the unfortunate monopolistic effects which result under the present system?

What legal and quasi-legal devices can be developed to enable the courts and administrative bodies to carry out the policies and achieve the objectives of the patent system more effectively than is done at the present time?

Might the "progress of science and useful arts" be furthered by government participation in the effort, beyond the present participation consisting of granting patents for invention? If so, what should be the form and scope of such participation? Should it embrace those research activities which private industry is not prepared to undertake, even with the stimulus provided by the patent system, e.g., certain types of basic research, atomic energy, etc.? Or should the Government go farther and play the role which it has sometimes played in other fields-using its resources to keep our economy on an even keel by throwing its weight into one side of the scale or the other to provide and stimulate competition in research-and, if it can be done, restore the small business or individual inventor to a place in the research field?

Does the present interrelationship between productive industry and research pose problems for free competitive enterprise which can be solved only by the divorcement of business interests from patent interests? As a less drastic alternative, might business interests be permitted to retain a patent position, but only on condition that the patents be endowed with a "business affected with a public interest" concept, connoting the common-law obligations of such a business to serve all without discrimination and at reasonable rates?

Until serious attention is given to these basic issues, efforts to patch up the system here and prune it there will have little more significance than taking aspirin for a headache caused by a basic illness. 